\title{
Evaluation of iron metabolism indices and their relation with physical work capacity in athletes
}

\author{
S O Karamızrak, Ç Işlegen, S R Varol, Y Taşkıran, Ç Yaman, I Mutaf, N Akgün
}

\begin{abstract}
Objective-To evaluate the relation between iron status and physical working capacity, and to assess the effect of oral iron treatment on these variables, in athletes with borderline iron status.

Methods-Blood haemoglobin (Hb), packed cell volume (PCV), red blood cell count (RBC), serum iron, total iron binding capacity (TIBC), and ferritin determinations were compared in 71 male and 18 female athletes participating in various sports and in matched male $(n=11)$ and female $(n=8)$ controls. The first aim was to assess the relations between these variables and performance in a physical work capacity test $\left(\mathbf{P W C}_{170}\right)$. Oral iron treatment $(175-350 \mathrm{mg}$ ferrous fumarate daily) was provided for three weeks to six male and five female athletes with borderline $\mathrm{Hb}$ concentrations, to determine the effects of such treatment on both iron status and performance.

Results-Among females, handball players had the lowest serum ferritin concentrations $(P<0.05)$, the highest TIBC values, and lowest PWC $_{170}$ scores $(P<0.01)$; runners had the highest ferritin concentrations and $\mathbf{P W C}_{170}$ scores $(P<0 \cdot 01)$. There were significant correlations $(P<0 \cdot 01)$ between $P W C_{170}$ and PCV, serum ferritin, and transferrin saturation of female athletes. Hb, serum iron, serum ferritin, and transferrin saturation increased with iron treatment in both males $(P<0.01)$ and females $(P<0.05)$.

Conclusions-Serum ferritin determination may prove a valuable addition to the screening of athletes and may indicate the need for iron treatment, even though a causal effect on improvement of work capacity may not be present.

(BrF Sports Med 1996;30:15-19)
\end{abstract}

Key terms: exercise; exertion; iron deficiency; sports anaemia; serum ferritin

Iron deficiency occurs as a result of an imbalance between iron absorption and excretion. ${ }^{1}$ Absorption is in inverse relation to body iron stores, ${ }^{12}$ and the serum concentration of ferritin is considered to be an index of these stores, $1 \mu \mathrm{g} \cdot$ litre $^{-1}$ corresponding to $8-10 \mathrm{mg}$ of body iron. ${ }^{1-3}$ The aetiology of exercise related iron deficiency includes intravascular haemolysis, increased iron loss, and inadequate dietary iron intake. ${ }^{4}$ Though no significant difference between the haematological status of athletes in various sports is reported, ${ }^{6}$ iron loss is known to be increased in endurance activities. ${ }^{3}$ Haemodilution by a relative increase in resting plasma volume in runners is an important reason for low haematological values, especially in highly trained athletes. ${ }^{45-9}$ In the long run, the increase in blood volume may become more equally distributed between the plasma volume and the red cell mass. ${ }^{9}$ Furthermore, in some studies $^{8} 10$ no differences were observed between the distribution of iron indices in runners and controls.

Single haemoglobin $(\mathrm{Hb})$, serum ferritin, and transferrin saturation measurements are not sufficient to determine the phases of iron deficiency. ${ }^{5}$ In the prelatent deficiency phase, as serum ferritin decreases to $30-60 \mu \mathrm{g} \cdot$ litre $^{-1}$, other indices are not yet affected. In latent deficiency serum ferritin falls below 30 $\mu \mathrm{g} \cdot$ litre $^{-1}$, transferrin saturation decreases to $15-20 \%$, serum iron concentrations may decrease, and total iron binding capacity (TIBC) may increase..$^{211} 12$ In overt iron deficiency anaemia, serum ferritin concentration is less than $12 \mu \mathrm{g} \cdot$ litre $^{-1}$, and $\mathrm{Hb}$ is below 130-140 g.litre ${ }^{-1}$ in males and below $120 \mathrm{~g} \cdot$ litre $^{-1}$ in females. $^{281112}$ Based on serum ferritin values, iron stores of athletes are reported to be about $30 \%$ less than normal, and in young women with low dietary haem iron, the incidence of iron deficiency may reach $50 \% .^{12}$

In iron deficiency anaemia, along with other clinical findings, work capacity and $\mathrm{VO}_{2}$ max decrease as a result of lowered Hb levels. ${ }^{1-3} 12$ Iron related enzyme activities of athletes with iron deficiency are found to be only as low as values in sedentary people and the primary effect is on $\mathrm{Hb}^{13}$ The observation that $\dot{\mathrm{VO}}_{2} \max$ and total exercise duration values return to normal when serum iron, transferrin saturation, and serum ferritin stay low in subjects who have undergone venesection once their $\mathrm{Hb}$ levels are restored by transfusion shows that the fall in endurance in the anaemic state is associated with lower $\mathrm{Hb}$, and not lower skeletal muscle enzyme activities. ${ }^{14}$ In fact, $\mathrm{Hb}$ has been found to be an important determinant of $\mathrm{O}_{2}$ diffusion rates into the working muscle, and a reduction in $\mathrm{Hb}$ results in decreased $\dot{\mathrm{VO}}_{2}$ max because of depressed $\mathrm{O}_{2}$ delivery and diffusing capacity. ${ }^{15}$ Furthermore, total body $\mathrm{Hb}$ is found to influence $\mathrm{VO}_{2}$ max principally, whereas low $\mathrm{Hb}$ concentration has a greater effect on performance time. ${ }^{16}$

The iron status of women distance runners was found similar to that of sedentary people, with only serum ferritin concentration having the tendency to decrease in elite athletes. ${ }^{17}$ 
Serum ferritin concentrations in female hockey players tended to fall below $20 \mu \mathrm{g} \cdot$ litre $^{-1}$ following three to four seasons. ${ }^{18}$ In contrast, swimmers were reported to have better haematological status than sedentary people. ${ }^{19}$

Some studies have shown that both $\mathrm{Hb}$ and serum ferritin levels improved following oral iron treatment. ${ }^{2021}$ Others found that only serum ferritin levels were corrected upon treatment of iron depletion without overt anaemia. ${ }^{11} 22{ }^{23}$ Investigators who gave a daily iron supplement of about $100 \mathrm{mg}$ to female runners for 8 to 10 weeks observed that, while serum ferritin levels increased rapidly, blood lactate and $\mathrm{V}_{2}$ max or work capacity was unchanged, ${ }^{21} 2425$ whereas running time could improve $^{26}$ or remain stable $\mathrm{e}^{2327}$ with a similar treatment. Restored oxygen utilisation and postexercise lactate following repletion of iron stores is also reported. ${ }^{22}$

In view of these conflicting reports, our aim in this study was to compare several haematological indices in athletes performing different sports, to evaluate the relationship between iron status and physical work capacity, and to assess the effect of oral iron treatment on these indices in athletes with borderline iron status.

\section{Methods}

SUBJECTS

Male athletes $(n=71)$ included 17 professional and 11 amateur soccer players, six national level wrestlers, seven swimmers, 11 middle distance runners, 12 second league basketball players, and seven body builders. Female athletes $(n=18)$ comprised 11 national league handball players, four swimmers, and three short or middle distance runners. The control groups consisted of 11 male and eight female university students not actively participating in sports. The subjects had no iron medication for the previous three weeks and had not accomplish any physical activity for the previous 24 hours.

\section{PROCEDURE}

Subjects reported to the laboratory at 9:30 am, at least three hours after a light breakfast, and their physical measurements were taken. After a sitting rest of $15 \mathrm{~min}$, blood samples were withdrawn with minimum stasis from a forearm vein. Finger prick blood samples were also obtained for RBC, packed cell volume (PCV), and $\mathrm{Hb}$ measurements. Upon centrifuging the blood samples after a period of $30 \mathrm{~min}$ for clotting, clear sera were kept at $-4^{\circ} \mathrm{C}$ for $48 \mathrm{~h}$ for serum iron and TIBC measurements and another portion was kept at $-20^{\circ} \mathrm{C}$ for up to two months for serum ferritin determinations.

\section{PWC $_{170}$ TEST PROTOCOL}

The subjects performed a physical work capacity test $\left(\mathrm{PWC}_{170}\right.$ ) on a mechanically braked Monark 868 bicycle ergometer (Varberg). They warmed up for $5 \mathrm{~min}$ at a speed of $60 \mathrm{rpm}$ against a resistance of $1.0 \mathrm{kp}$ and rested for $2 \mathrm{~min}$. Then, while the speed was kept constant, the resistance was increased by 0.5 to $1.0 \mathrm{kp}$ every $2 \mathrm{~min}$. Heart rates were monitored using a Hellige Cardiotest EK 41 ECG apparatus and the test was completed upon approaching a heart rate of 170 beats $\mathrm{min}^{-1}$.

\section{HAEMATOLOGICAL TESTS}

RBC and PCV measurements were performed by standard techniques and $\mathrm{Hb}$ levels were determined using Zijlstra's cyanomethaemoglobin method. Serum iron and TIBC analyses were performed using the semi-micro bathophenanthroline method (Merckotest 3307 and 3313, Merck) with an LKB K 4053 spectrophotometer. Transferrin saturation was calculated as the percent ratio of serum iron to TIBC. Serum ferritin measurements were done using a radioimmunoassay method (Amerlex Ferritin RIA, Amersham).

IRON TREATMENT

Following the first test, six of the male athletes with $\mathrm{Hb}$ concentrations below $140 \mathrm{~g} \cdot$ litre $^{-1}$ and PCV values below $43 \%$, and five of the female athletes with $\mathrm{Hb}$ concentrations below 130 $\mathrm{g} \cdot$ litre $^{-1}$ and PCV values below $40 \%$ were treated for three weeks, using $350 \mathrm{mg}$ and 175 $\mathrm{mg}$ of ferrous fumarate daily, respectively, equivalent to $112 \mathrm{mg}$ and $56 \mathrm{mg}$ of elemental iron. These subjects had no apparent parasitic or bacterial infections. All measurements were repeated one week after completion of the treatment.

\section{STATISTICS}

Means and standard deviations were calculated for all variables. Analyses of variance (ANOVA) were performed to compare the results of different groups. Unpaired Student's t tests were applied to compare the results of pairs of groups, and paired t tests to evaluate the effect of iron treatment, and correlation coefficients for within-group variables were obtained, all using the Minitab program.

\section{Results}

Mean values of the physical, haematological and serum indices for the male subjects are presented in table 1 , and those for the female subjects are given in table 2 . The pre- and posttreatment values of the subjects treated with oral iron are compared in table 3.

Blood RBC and PCV counts, and $\mathrm{Hb}$ and serum iron concentrations were found to be within the expected normal range for all subjects. Mean TIBC values of the male subjects were at the lower limit of the normal range of $54-71 \mu \mathrm{mol} \cdot \mathrm{litre}^{-1}$. For the male athletes, only the runners' $R B C$ counts were observed to be lower than the controls' $(P<0.01)$ - with no significant differences in iron indices $(P>0.05)$ - when comparing different sports. Runners had significantly higher $\mathrm{PWC}_{170}$ scores $(\mathrm{P}<0.01)$ compared with other disciplines.

Female handball players who had lower serum ferritin concentrations $(P<0.05)$ than the controls had also the highest TIBC values and lowest working capacity $(P<0.01)$ among all female athletes. Female runners had the 
Table 1 Physical, haematological, and serum indices of male subjects. Values are mean (SD)

\begin{tabular}{|c|c|c|c|c|c|c|c|c|c|}
\hline Discipline & $\begin{array}{l}\text { Professional } \\
\text { football } \\
(n=17)\end{array}$ & $\begin{array}{l}\text { Wrestling } \\
(n=6)\end{array}$ & $\begin{array}{l}\text { Swimming } \\
(n=7)\end{array}$ & $\begin{array}{l}\text { Running } \\
(n=11)\end{array}$ & $\begin{array}{l}\text { Basketball } \\
(n=12)\end{array}$ & $\begin{array}{l}\text { Amateur } \\
\text { football } \\
(n=11)\end{array}$ & $\begin{array}{l}\text { Body } \\
\text { building } \\
(n=7)\end{array}$ & $\begin{array}{l}\text { Total } \\
\text { athletes } \\
(n=71)\end{array}$ & $\begin{array}{l}\text { Controls } \\
(n=11)\end{array}$ \\
\hline & $23+3+2$ & & 1) & 7) & 22 & 21 & 21 & $(3 \cdot 3)$ & 1.0) \\
\hline & 174 & & & 174 & $191.6(7.5)$ & $175.0(6.2)$ & $172.9(9.4)$ & $177 \cdot 4(9.8)$ & $175.5(5.7)$ \\
\hline Weig & $71 \cdot 0(6 \cdot 1)$ & $79 \cdot 3(15 \cdot 7)$ & $71 \cdot 4(6 \cdot 3)$ & $65.9(6.9)$ & $85.5(9.9)$ & $69.9(7.8)$ & $78.6(11.8)$ & $74.0(10 \cdot 7)$ & $70 \cdot 6(9 \cdot 6)$ \\
\hline PWC (W. $\left.\mathrm{kg}^{-1}\right)$ & $3.00(0.38)$ & $2.59(0.70)$ & $3.07(0.56)$ & $3.62^{\star}(0.54)$ & $3.31(0.47)$ & $3.13(0.38)$ & $2.66(0.27)$ & $3.11(0.54)$ & $2 \cdot 20(0.46)$ \\
\hline RBC $\left(10^{12} \cdot\right.$ litre $\left.^{-1}\right)$ & & $4.67(0.57)$ & 42) & $4.09+$ & $4 \cdot 6$ & $4 \cdot 4$ & 4.5 & 4.45 & $0.60)$ \\
\hline PCV $(\%)$ & $43 \cdot 5$ & $45 \cdot 8(1 \cdot 2)$ & $46 \cdot 3(2 \cdot 4)$ & $45 \cdot 2(2 \cdot 8)$ & $45 \cdot 7(1 \cdot 6)$ & $44 \cdot 4(3 \cdot 5)$ & $45 \cdot 6(2 \cdot 6)$ & $44.9(2 \cdot 6)$ & $45 \cdot 5(2 \cdot 5)$ \\
\hline $\mathrm{Hb}\left(\mathrm{g}\right.$. litre $\left.{ }^{-1}\right)$ & $146 \cdot 7(10 \cdot 9)$ & $145.0(8.5)$ & $154.9(7.8)$ & $146.6(9.9)$ & $153.3(5.4)$ & $152.6(7 \cdot 5)$ & $153.6(10.8)$ & $149.9(9.3)$ & $5(9 \cdot 1)$ \\
\hline ol-litre $\left.e^{-1}\right)$ & $19 \cdot 2(5.9)$ & $18.7(5.4)$ & $18.0(4.2)$ & $19 \cdot 1$ & $18 \cdot 5$ & $16 \cdot 7(4 \cdot 1)$ & $20 \cdot 8$ & $18 \cdot 7(6 \cdot 4)$ & $18 \cdot 8(11 \cdot 6)$ \\
\hline TIBC $\left(\mu \mathrm{mol} \cdot\right.$ litre $\left.^{-1}\right)$ & $50 \cdot 2(7 \cdot 7)$ & $52 \cdot 4(4 \cdot 7)$ & $53 \cdot 2(7 \cdot 3)$ & $51 \cdot 0(7 \cdot 2)$ & $54.9(13.4)$ & $58.6(9 \cdot 0)$ & $60.9(9 \cdot 0)$ & $54 \cdot 0(9 \cdot 3)$ & $58 \cdot 6(10 \cdot 1)$ \\
\hline & $38 \cdot 2(12 \cdot 6)$ & & & & & & & 35 . & .2) \\
\hline SF $\left(\mu \mathrm{g} \cdot\right.$ litre $\left.^{-1}\right)$ & $60 \cdot 4(31 \cdot 3)$ & $79 \cdot 5(52 \cdot 0)$ & $58.4(22.4)$ & $64.5(45.4)$ & $77.9(41.0$ & $75 \cdot 6(34 \cdot 2)$ & $(54 \cdot 5)$ & $70 \cdot 4(39 \cdot 1)$ & $87 \cdot 3(42 \cdot 4)$ \\
\hline
\end{tabular}

PWC = physical work capacity; $\mathrm{PCV}=$ packed cell volume; $\mathrm{Hb}=$ haemoglobin; $\mathrm{SI}=$ serum iron; TIBC = total iron binding capacity; TS = transferrin saturation; $\mathrm{SF}=$ serum ferritin.

${ }^{\star} \mathrm{P}<0.01 v$ other disciplines; $\uparrow \mathrm{P}<0.01 v$ controls; two-sample Student test.

highest $\mathrm{PWC}_{170}$ scores and the highest serum ferritin concentrations $(P<0.01)$.

For all female athletes, $\mathrm{PWC}_{170}$ levels correlated $(P<0.01)$ with $P C V \quad(r=0.60)$, serum ferritin $(r=0.55)$, and transferrin saturation $(r=0.53)$. When the relation of different variables with PWC $_{170}$ was assessed in different disciplines, significant correlations were found for transferrin saturation in female swimmers $(r=0.96, \mathrm{P}<0.05)$ and for $\mathrm{Hb}$ in body builders $(r=0.75, P<0.05)$.

Following iron treatment, $\mathrm{Hb}$, serum iron, and serum ferritin concentrations increased both in males $(P<0.01)$ and females $(P<0 \cdot 05)$. Male subjects responded with a significant increase in transferrin saturation $(\mathrm{P}<0.01)$ as well. While females increased their $\mathrm{PWC}_{170}$ scores by $11 \%(\mathrm{P}>0.05)$, no such effect was recorded for the males.

\section{Discussion}

Group means for most of the iron metabolism indices were within the normal range, conform to the observations of Balaban et al, ${ }^{10}$ Durstine et $a l,{ }^{17}$ and Weight et al. ${ }^{8}$ The slightly raised serum iron concentrations obtained for most of the subjects may be explained by the fact that the exercise test was carried out about three hours after a light breakfast, to obtain a better performance in the ergometer test, thus adding to the biological variation of this index, which is already reported to be high. ${ }^{3}$ Mean TIBC values close to the lower limit of the normal range may indicate some form of transferrin deficiency.

Being more endurance trained, male runners had higher PWC $_{170}$ scores compared with other athletes. While most of their indices were comparable with the observations of Weight et $a l^{8}$ a higher plasma volume expansion may explain their somewhat lower RBC values. ${ }^{5} 820$ This observation parallels those of Hallberg and Magnusson ${ }^{7}$ and Weight et al. ${ }^{28}$ Though not significant, the higher PCV and $\mathrm{Hb}$ values of the male swimmers, and the higher RBC and PCV levels encountered in their female counterparts, are in agreement with the observations of Pelliccia et al. ${ }^{19}$ Otherwise, there were no significant differences in haematological status of the male athletes in various sports, in agreement with Biancotti and coworkers. ${ }^{6}$ Female handball players, who have been competing in the national league for at least three seasons, had the lowest mean serum ferritin concentrations of $13.6 \mu \mathrm{g} \cdot$ litre $^{-1}$, in agreement with the results of Diehl et $a l^{18}$ for female hockey players. This low value may be explained by poor dietary habits of the players as a team. Again, high PWC ${ }_{170}$ scores in the female athletes is a result of their being more highly trained.

With regard to serum ferritin concentrations, only three $(17 \%)$ of the female athletes were in the normal range, another three were in a state of prelatent iron deficiency, having serum ferritin levels less than $60 \mu \mathrm{g} \cdot$ litre $^{-1}$, and the remaining $12(67 \%)$ were within the range of latent iron deficiency, with serum ferritin below $30 \mu \mathrm{g} \cdot$ litre $^{-1}$ and transferrin saturation below $20 \%,{ }^{211} 12$ which supports the observations of Nickerson and coworkers ${ }^{11}$ and Parr et $a l,{ }^{12}$ but not those of Risser et $a l^{20}$ and Weight et al. ${ }^{8} \mathrm{Hb}$ concentrations were between 120 and130 $\mathrm{g} \cdot$ litre $^{-1}$ for three athletes whose serum ferritin levels were below $20 \mu \mathrm{g} \cdot$ litre $^{-1}$, whereas for two female athletes, $\mathrm{Hb}$ concentrations were below $120 \mathrm{~g} \cdot$ litre $^{-1}$ and serum ferritin was below 12, which are accepted as being critical levels indicating iron deficiency anaemia. ${ }^{211}$ Though the female

Table 2 Physical, haematological, and serum indices of female subjects. Values are mean (SD)

\begin{tabular}{|c|c|c|c|c|c|}
\hline Discipline & $\begin{array}{l}\text { Handball } \\
(n=11)\end{array}$ & $\begin{array}{l}\text { Swimming } \\
(n=4)\end{array}$ & $\begin{array}{l}\text { Running } \\
(n=3)\end{array}$ & $\begin{array}{l}\text { Total athletes } \\
(n=18)\end{array}$ & $\begin{array}{l}\text { Controls } \\
(n=8)\end{array}$ \\
\hline Age (years) & $21 \cdot 5(1 \cdot 7)$ & $16 \cdot 0(0 \cdot 8)$ & $24 \cdot 3(4 \cdot 9)$ & $20 \cdot 7(3 \cdot 5)$ & $22 \cdot 3(1 \cdot 0)$ \\
\hline Height $(\mathrm{cm})$ & $168 \cdot 7(4 \cdot 0)$ & $162.8(5 \cdot 3)$ & $162 \cdot 3(2 \cdot 5)$ & $166 \cdot 3(5 \cdot 0)$ & $161.8(4 \cdot 7)$ \\
\hline Weight $(\mathrm{kg})$ & $60.6(5.8)$ & $54.8(3.5)$ & $55.8(3.8)$ & $58.5(5 \cdot 6)$ & $54 \cdot 2(5 \cdot 7)$ \\
\hline $\mathrm{PWC}_{170}\left(\mathrm{~W} \cdot \mathrm{kg}^{-1}\right)$ & $2 \cdot 25^{\star}(0 \cdot 51)$ & $2 \cdot 82(0.57)$ & $3 \cdot 20(0 \cdot 77)$ & $2 \cdot 54(0.66)$ & $1.98(0.40)$ \\
\hline RBC $\left(10^{12} \cdot\right.$ litre $\left.^{-1}\right)$ & $4 \cdot 08(0 \cdot 41)$ & $4.38(0.53)$ & $4.05(0.52)$ & $4 \cdot 14(0 \cdot 44)$ & $4.09(0.45)$ \\
\hline PCV (\%) & $39 \cdot 3(2 \cdot 8)$ & $41 \cdot 0(1 \cdot 2)$ & $40 \cdot 0(2 \cdot 0)$ & $39 \cdot 8(2 \cdot 4)$ & $39 \cdot 5(2 \cdot 2)$ \\
\hline $\mathrm{Hb}\left(\mathrm{g} \cdot\right.$ litre $\left.^{-1}\right)$ & $130 \cdot 1(12 \cdot 0)$ & $129.8(9 \cdot 2)$ & $142 \cdot 7(4 \cdot 0)$ & $132 \cdot 1(11 \cdot 2)$ & $133.2(7.9)$ \\
\hline SI $\left(\mu \mathrm{mol} \cdot \mathrm{litre}^{-1}\right)$ & $18 \cdot 5(6 \cdot 6)$ & $14 \cdot 3(5 \cdot 0)$ & $22 \cdot 1(4 \cdot 8)$ & $18 \cdot 2(4 \cdot 6)$ & $18.0(8.6)$ \\
\hline TIBC $\left(\mu \mathrm{mol} \cdot\right.$ litre $\left.^{-1}\right)$ & $65 \cdot 3 \star(9 \cdot 3)$ & $50.8(4.9)$ & $48.6(5 \cdot 3)$ & $59 \cdot 3(10 \cdot 9)$ & $57.9(10.0)$ \\
\hline TS $(\%)$ & $28.9(10.2)$ & $28 \cdot 7(14 \cdot 0)$ & $45.2(5.0)$ & $31.6(11 \cdot 7)$ & $31 \cdot 0(14 \cdot 8)$ \\
\hline SF $\left(\mu g \cdot \operatorname{litre}^{-1}\right)$ & $13.6 \dagger(8.4)$ & $35.7(24.5)$ & $97 \cdot 7^{\star}(67 \cdot 1)$ & $32 \cdot 6(40 \cdot 7)$ & $33.2(19 \cdot 4)$ \\
\hline
\end{tabular}

Abbreviations as in table 1 .

${ }^{\star} \mathrm{P}<0.01 v$ other disciplines; $+\mathrm{P}<0.05 v$ controls; two-sample Student test. 
Table 3 Physical, haematological, and serum indices of athletes on iron therapy. Values are mean (SD).

\begin{tabular}{|c|c|c|c|c|}
\hline Group & $\begin{array}{l}\text { Males, } \\
\text { pre-treatment } \\
(n=6)\end{array}$ & $\begin{array}{l}\text { Males, } \\
\text { post-treatment } \\
(n=6)\end{array}$ & $\begin{array}{l}\text { Females, } \\
\text { pre-treatment } \\
(n=5)\end{array}$ & $\begin{array}{l}\text { Females, } \\
\text { post-treatment } \\
(n=5)\end{array}$ \\
\hline Age (years) & $22 \cdot 3(2 \cdot 9)$ & $22 \cdot 3(2 \cdot 9)$ & $18 \cdot 6(3 \cdot 8)$ & $18 \cdot 6(3 \cdot 8)$ \\
\hline Height $(\mathrm{cm})$ & $171 \cdot 5(2 \cdot 7)$ & $171.5(2.7)$ & $166 \cdot 0(5 \cdot 7)$ & $166 \cdot 0(5 \cdot 7)$ \\
\hline Weight $(\mathrm{kg})$ & $65 \cdot 5(6 \cdot 6)$ & $65.4(6.8)$ & $57 \cdot 8(3 \cdot 3)$ & $57 \cdot 4(3 \cdot 2)$ \\
\hline$P W C_{170}\left(W \cdot k^{-1}\right)$ & $3.44(0.58)$ & $3.45(0.78)$ & $2 \cdot 26(0.43)$ & $2 \cdot 51(0 \cdot 18)$ \\
\hline RBC $\left(10^{12} \cdot\right.$ litre $\left.^{-1}\right)$ & - & $3.83(0.29)$ & $4.06(0.41)$ & $4 \cdot 12(0.51)$ \\
\hline PCV $(\%)$ & $42 \cdot 3(1 \cdot 5)$ & $43 \cdot 0(2 \cdot 0)$ & $39 \cdot 0(2 \cdot 4)$ & $40 \cdot 6(1 \cdot 7)$ \\
\hline $\mathrm{Hb}\left(\mathrm{g} \cdot\right.$ litre $\left.^{-1}\right)$ & $137 \cdot 7(8 \cdot 5)$ & $150 \cdot 8^{\star}(10 \cdot 4)$ & $126 \cdot 2(3 \cdot 8)$ & $129 \cdot 8+(3 \cdot 5)$ \\
\hline SI $\left(\mu \mathrm{mol} \cdot\right.$ litre $\left.^{-1}\right)$ & $14.9(4.9)$ & $18 \cdot 4^{\star}(4 \cdot 0)$ & $10.5(3.4)$ & $12 \cdot 7+(3 \cdot 4)$ \\
\hline TIBC $\left(\mu \mathrm{mol} \cdot\right.$ litre $\left.^{-1}\right)$ & $44 \cdot 6(8 \cdot 3)$ & $51 \cdot 0(9 \cdot 1)$ & $60.7(11.8)$ & $62 \cdot 9(9 \cdot 7)$ \\
\hline TS (\%) & $34 \cdot 2(12 \cdot 6)$ & $54 \cdot 9^{\star}(11 \cdot 3)$ & $18 \cdot 1(7 \cdot 2)$ & $20 \cdot 3(4 \cdot 4)$ \\
\hline SF $\left(\mu \mathrm{g} \cdot\right.$ litre $\left.^{-1}\right)$ & $44 \cdot 0(17 \cdot 3)$ & $57 \cdot 2^{\star}(14 \cdot 2)$ & $17 \cdot 6(12 \cdot 2)$ & $22 \cdot 0+(10 \cdot 1)$ \\
\hline
\end{tabular}

Abbreviations as in table 1.

${ }^{\star} \mathrm{P}<0.01 ;+\mathrm{P}<0.05 v$ pre-treatment values; two-sample Student test.

controls scored better, with three $(37 \%)$ in a state of prelatent and only one (12\%) in a state of latent iron deficiency, female athletes had a similar hematological status, as also observed by Durstine et al. ${ }^{17}$ Poor dietary habits and the high incidence of recurrent parasitic infections in Turkey may be partly responsible of the relatively low iron status of most of the subjects.

Of the male athletes, $30(42 \%)$ were found to be in a state of prelatent iron deficiency, and two $(3 \%)$ were already within the limits of latent iron deficiency, with another having only a serum ferritin below $30 \mu \mathrm{g} \cdot \operatorname{litre}^{-1}$ and two more having only a transferrin saturation below $20 \%$. Interestingly, $\mathrm{Hb}$ concentrations in two professional soccer players were between 130 and $135 \mathrm{~g} \cdot$ litre $^{-1}$, approaching the limit for iron deficiency anaemia. As judged by serum ferritin concentrations, three of the male controls $(27 \%)$ were in a state of latent iron deficiency. Balaban et al ${ }^{10}$ observed similar conditions in athletes and controls.

The correlations calculated for female athletes between their PWC $_{170}$ levels and PCV values, serum ferritin concentrations, and transferrin saturation ratios $(P<0.01)$, and those between $\mathrm{PWC}_{170}$ scores and $\mathrm{Hb}$ concentrations for the body builders $(P<0.05)$ are interesting. Still, the small number of subjects suggests that these figures must be interpreted with caution.

The significant increases obtained in blood $\mathrm{Hb}$, serum iron, and serum ferritin concentrations upon iron treatment, both in males $(P<0.01)$ and females $(P<0.05)$, and in transferrin saturation ratios in the males $(P<0.01)$, proved the presence of iron deficiency. ${ }^{4}$ The relatively high pretreatment serum ferritin values observed in the males should be assessed with caution, since serum ferritin is an acute phase protein which increases with strenuous training. ${ }^{29}$ The greater improvement in haematological status of the male subjects compared to the females may be explained by the higher oral iron doses they received. In fact, about 16 weeks of such treatment seem to be needed ${ }^{25}$ for a gain of 45-50 $\mu \mathrm{g} \cdot \operatorname{litre}^{-1}$ in serum ferritin. These findings support those of Matter and coworkers $^{24}$ and Fogelholm et $a l^{21}$ who gave $50 \mathrm{mg}$ per day of iron for 10 weeks and $100 \mathrm{mg}$ per day of iron for eight weeks, respectively, to female runners, and those of Risser et $a l^{23}$ who also gave iron supplements to athletes with iron deficiency; but they disagree with those of Nickerson et al, ${ }^{11}$ Lukaski $e t a l,{ }^{22}$ Telford et $a l,,^{23}$ and Newhouse et $a l,{ }^{25}$ who did not observe increases in $\mathrm{Hb}$ levels. A reason for this may be the lower initial $\mathrm{Hb}$ concentrations in the present study compared to the ones they reported. No significant increases in $\mathrm{PWC}_{170}$, an index of endurance capacity, was observed either, in agreement with various other investigators. ${ }^{13} 2123-2527$ Training effect may be partly responsible of the rise in the females' PWC $_{170}$ scores.

The evidence from this study suggests that for athletes participating in various sports, and especially for female athletes, serum ferritin may be the first indication of prelatent iron deficiency, at a time when $\mathrm{Hb}$ and serum iron concentrations, transferrin saturation ratios, and RBC and PCV counts are not yet affected. A significant linear relation was even observed between physical working capacity and serum ferritin concentrations for female athletes. There were no striking differences in iron status in athletes in various disciplines. Treatment of borderline iron status resulted in increased $\mathrm{Hb}$, serum ferritin, serum iron, and transferrin saturation levels, but this was not accompanied by an increase in physical working capacity. The determination of serum ferritin concentrations, especially in the preseason period, may prove valuable as an indication for treatment, after ruling out bacterial and parasitic infections.

The authors acknowledge the Ege University Research Fund for supporting this project.

1 Finch CA, Huebers $\mathrm{H}$. Perspectives in iron metabolism. $N$ Engl f Med 1982;306:1520-8.

2 Finch CA, Cook JD. Iron deficiency. Am $f$ Clin Nutr 1984;39:471-7.

3 Haymes EM. Nutritional concerns: need for iron. Med Sci Sports Exerc 1987;19(suppl):S197-200.

4 Eichner ER. Sports anemia, iron supplements, and blood doping. Med Sci Sports Exerc 1992;24(suppl):S315-8.

5 Watts E. Athletes' anaemia. A review of possible causes and guidelines on investigation. Br f Sports Med 1989; 23:81-3.

6 Biancotti PP, Caropreso A, Di Vincenzo GC, Ganzit GP, Gribaudo CG. Hematological status in a group of male athletes of different sports. F Sports Med Phys Fitness 1992;32:70-5.

7 Hallberg L, Magnusson B. The etiology of "sports anemia". Acta Med Scand 1984;216:145-8.

8 Weight LM, Klein M, Noakes TD, Jacobs P. "Sports anemia" - A real or apparent phenomenon in endurancetrained athletes? Int $\mathcal{f}$ Sports Med 1992;13:344-7.

9 Convertino VA. Blood volume: its adaptation to endurance training. Med Sci Sports Exerc 1991;23:1338-48.

10 Balaban EP, Cox JV, Snell P, Vaughan RH, Frenkel EP. The frequency of anemia and iron deficiency in the runner. frequency of anemia and iron deficien

11 Nickerson HJ, Holubets $M$, Tripp AD, Pierce WE. Decreased iron stores in high school female runners. $\mathrm{Am}$ f Dis Child 1985;139:1115-9.

12 Parr RB, Bachman LA, Moss RA. Iron deficiency in female athletes. Phys Sportsmed 1984;12(4):81-6.

13 Clarkson PM. Minerals: exercise performance and supplementation in athletes. $\mathcal{F}$ Sports Sci 1991;9(suppl): 91-116.

14 Celsing F, Blomstrand E, Werner B, Pihlstedt P, Ekblom B. Effects of iron deficiency on endurance and muscle enzyme activity in man. Med Sci Sports Exerc 1986;18:156-61

15 Schaffartzik W, Barton ED, Poole DC, Tsukimoto K, Hogan MC, Bebout DE, et al. Effect of reduced hemoglobin concentration on leg oxygen uptake during maximal exercise in humans. F Appl Physiol 1993; 75:491-8.

16 Kanstrup IL, Ekblom B. Blood volume and hemoglobin concentration as determinants of maximal aerobic power. Med Sci Sports Exerc 1984;16:256-62.

17 Durstine JL, Pate RR, Sparling PB, Wilson GE, Senn MD, Bartoli WP. Lipid, lipoprotein, and iron status of elite women distance runners. Int $\mathcal{f}$ Sports Med 1987; 8(suppl):S119-23. 
18 Diehl DM, Lohman TG, Smith SC, Kertzer R. Effects of physical training and competition on the iron status of female field hockey players. Int $\mathcal{f}$ Sports Med 1986; 7:264-70.

19 Pelliccia A, Di Nucci GB. Anemia in swimmers: fact or fiction? Study of hematologic and iron status in male and female top-level swimmers. Int $\mathcal{f}$ Sports Med 1987;8:227-30.

20 Risser WL, Lee EJ, Poindexter HBW, West MS, Pivarnik $\mathrm{JM}$, Risser JMH, et al. Iron deficiency in female athletes: ts prevalence and impact on performance. Med Sci Sports Exerc 1988;20:116-21.

21 Fogelholm M, Jaakkola L, Lampisjärvi T. Effects of iron supplementation in female athletes with low serum ferritin concentration. Int $\mathcal{F}$ Sports Med 1992;13:158-62.

22 Lukaski HC, Hall CB, Siders WA. Altered metabolic response of iron-deficient women during graded, maximal response of iron-deficient women during gradec

23 Telford RD, Bunney CJ, Catchpole EA, Catchpole WR Deakin V, Gray B, et al. Plasma ferritin concentration and physical work capacity in athletes. Int $\mathcal{f}$ Sport Nutr 1992;2:335-42.
24 Matter M, Stittfall T, Graves J, Myburgh K, Adams B, Jacobs $\mathrm{P}$, et al. The effect of iron and folate therapy on maximal exercise performance in female marathon runners with iron and folate deficiency. Clin Sci 1987;72:415-22.

25 Newhouse IJ, Clement DB, Taunton JE, McKenzie DC. The effects of prelatent/latent iron deficiency on physical work capacity. Med Sci Sports Exerc 1989;21:263-8.

26 Rowland TW, Deisroth MB, Green MG, Kelleher JF. The effect of iron therapy on the exercise capacity of nonanemic iron deficient adolescent runners. $A m \mathcal{F} D$ is Child 1988;142:165-9.

27 Klingshirn LA, Pate RR, Bourque SP, Davis JM, Sargent RG. Effect of iron supplementation on endurance capacity in iron-depleted female runners. Med Sci Sports

28 Weight LM, Darge BL, Jacobs P. Athletes' pseudoanaemia. Eur F Appl Physiol 1991;62:358-62.

29 Dickson DN, Wilkinson RL, Noakes TD. Effects of ultramarathon training and racing on hematologic parameters and serum ferritin levels in well-trained athletes. Int $\mathcal{f}$ Sports Med 1982;3:111-7.

\title{
1996 BASM ANNUAL CONGRESS
}

Thursday 31 October-Sunday 3 November

at

Newcastle, Co Down, Northern Ireland

\section{SPORTS MEDICINE INTO THE 21st CENTURY}

\author{
Keynote speakers: \\ Prof Per Renström \\ Vermont, USA \\ Prof David Costill \\ Indiana, USA \\ Dr Willem van Mechelen Amsterdam, Holland
}

\section{Topics will include:}

- Physiological, psychological and pharmacological limits to performance in sport, physical activity and health - new challenges for the health carers.

- The ankle - a complete overview of acute, recurring and chronic injury and its rehabilitation.

- Advances in imaging.

- Pre-hospital care of the acutely injured sportsman.

Scientific papers and posters will be presented and displayed. We are now looking for abstracts.

For further information regarding the scientific programme, abstract submission or booking arrangements please contact:

\author{
Dr Robin Harland MB FRCGP FISM \\ 6 Castlehill Road \\ BELFAST BT4 3GL \\ Northern Ireland \\ Telephone: 01232653682 Fax: 01232473540 \\ E-Mail: R.Harland@QUB.AC.UK
}

The setting for the 1996 Conference is in an area of outstanding beauty with facilities for many sporting activities. This is a perfect opportunity to combine a Conference of high standard with a short break in a new setting and to experience our famous Irish hospitality.

Full PGEA approval sought. 